\title{
Effect of lactation number on milk yield in Holstein dairy cows
}

\author{
Funda Eşki ${ }^{1}$ Serdal Kurt $^{2}$ (๑) \\ ${ }^{1}$ Department of Obstetrics and Gynaecology, Faculty of Ceyhan Veterinary Medicine, Çukurova University, Adana, Turkey \\ ${ }^{2}$ Department of Obstetrics and Gynaecology, Faculty of Veterinary Medicine, Dicle University, Diyarbakır, Turkey.
}

\begin{abstract}
Objective: Aim of the present study was to determine the effect of the lactation number on milk production and to detect the most economical lactation period in Holstein dairy cows.

Materials and Methods: The animal materials of the study were 392 Holstein dairy cows with a similar dry period and lactation length. The cows were divided into 6 groups according to the number of lactations. The groups were formed as 1st lactation (Group 1; n=67), 2nd lactation (Group 2; n=124), 3rd lactation (Group 3; n=51), 4th lactation (Group 4; $\mathrm{n}=62$ ), 5th lactation (Group 5; $\mathrm{n}=41$ ) and 6th lactation (Group 6; $\mathrm{n}=47)$.

Results: Average lactation milk yields for the 1st, 2nd, 3rd, 4th, 5th, and 6th lactations of the cows used in the study were $7860.03 \mathrm{~kg}, 9010.02 \mathrm{~kg}, 10207.15 \mathrm{~kg}, 10165.89 \mathrm{~kg}, 8430.57 \mathrm{~kg}$ and $8069.78 \mathrm{~kg}$, respectively. It was determined that the highest milk production and highest daily income were obtained during the 3rd and 4 th lactation periods $(\mathrm{p}<0.05)$.
\end{abstract}

Conclusion: In conclusion, milk production increased in the first three lactations, 3 and 4 lactation remained stable and decreased in 5th and 6th lactations. But, regardless of the number of lactations during the first 6 lactation periods, it is considered economical to use healthy cows for milk production in dairy farms.

Keywords: Cows, Lactation number, Milk production

\section{INTRODUCTION}

Traditionally, breeding programs for livestock animals have focused on the advancement of economically important production traits (Oltenocu and Broom, 2010). For this purpose, milk production has always been one of the most important parameters, and many studies have been carried out to increase milk yield per dairy cow (Zadoks and Fitzpatrick, 2009; Oltenoce and Broom, 2010; O'Hara et al., 2020). In the last three quartercentury, annual milk production per cow has been increased around 4-fold with successful genetic selection and other rehabilitation studies (Abuelo et al., 2019). It has also been reported that it should focus on lifelong production and longevity due to its environmental impact and animal welfare (Oltenoce and Broom, 2010). Due to the increase in milk production, it has become difficult to meet nutritional needs especially during the early lactation period (Walsh et al., 2011). And it is known that the high-yielding dairy cows experience negative energy balance up to the first 6 weeks postpartum (Bisinotto et al., 2012). Consequently, the increased milk yield has been accompanied by an increase in the production of diseases and culling rates (Esposito et al., 2014). On the other hand, pathological and physiological factors affecting milk production must be tackled and kept within ideal limits for sustainable profitability in milk production. However, many pathological and physiological factors affect milk production and are 
caused by management inaccuracies in dairy cows (Short and Lawlor, 1992; Leblanc, 2010). Some of the important physiological factors that affect milk production in healthy dairy cows are dry period length ( $\mathrm{O}^{\prime}$ Hara et al., 2020) and lactation number (De Vries and Marcondes, 2020). Lactation numbers can affect the milk yield and composition in dairy cows (Vijayakumar et al., 2017). It is also known that aging has an impact on milk production (Holodova et al., 2019). Dairy cows need to be fully matured for optimum milk production (De Vries and Marcondes, 2020). Although dairy cows live longer than 10 lactations, their average productive life is only 3 or 4 lactations (Sott, 1994). Based on this information, it is thought that knowing the most productive lactation periods will have economic benefits. Therefore, we hypothesized that the lactation number might have a role in the annual milk yield of dairy cattle. The present study aimed to determine the effect of the lactation number on milk production and to detect the most economical lactation period in Holstein dairy cows.

\section{MATERIALS and METHODS}

\section{Animals and management}

For the presented study, the ethics committee approval was obtained from the Local Ethics Committee of Ceyhan Veterinary Faculty, Çukurova University (decision 09.07.2020 and $02 / 01$ ). The animal material of the present study was 392 Holstein dairy cows with lactation numbers between 1 and 6 . The cows were managed in freestall barns, fed according to their individual needs with free access to water, and milked twice a day. All cows had a dry period length of around 60 days. At the beginning of the dry period, selective dry period treatment was performed on all dairy cows under the control of the farm veterinarian. The dairy cows routinely received early dry period (faroff), late dry period (close-up), fresh cow, early lactation, mid-lactation, and late lactation diets. The chemical content of the ration changed according to the stage of lactation and dry period. The health of the cows was checked periodically by the farm veterinarian. Clinical examinations were performed periodically at every stage of lactation, especially during group changes, and included rectal temperature, respiratory, appetite, physical posture, daily milk production, and routine udder checks. Cows with any health problems were registered in the farm registry system. Cows used in the present study were clinically healthy during the lactation period and did not have a problem that would negatively affect milk yield. The cows were divided into 6 groups according to the number of lactations. The groups were formed as 1 st lactation (Group 1; n=67), 2nd lactation (Group 2; n=124), 3rd lactation (Group 3; $\mathrm{n}=51$ ), 4th lactation (Group 4; $\mathrm{n}=62$ ), 5th lactation (Group 5; $\mathrm{n}=41$ ) and 6th lactation (Group $6 ; n=47$ ) by the randomized grouping method. The colostrum period was defined as the first 5 days postpartum (Tsioulpas et al., 2007), and milk yield after this period was taken into account. Total milk production from initiation of lactation to end of lactation was recorded for each group of the cows. And daily average milk yield was calculated by the ratio of total milk yield to lactation days. Raw milk price was determined according to the national milk council 2019 recommendation price (USK, 2019).

\section{Statistical analysis}

Analysis of all datasets was performed statistically with SPSS (Version: 22.0; IBM, USA). The normality test of the data obtained from the research was performed with the Kolmogorov-Smirnov test. As a result of the normality test, one-way analysis of variance (ANOVA) and Duncan multiple comparison test were applied to reveal differences between group averages. The significance level was accepted as $p<0.05$. The results of the study were presented as the mean \pm standard deviation of the mean (SD).

Table 1. The effect of lactation number on lactation milk yield in Holstein dairy cows.

\begin{tabular}{cccc}
\hline $\begin{array}{c}\text { Lactation } \\
\text { Number }\end{array}$ & $\begin{array}{c}\text { Cow } \\
\text { Number }\end{array}$ & $\begin{array}{c}\text { Lactation Milk } \\
\text { Yield Mean (kg) }\end{array}$ & $\begin{array}{c}\text { Std. } \\
\text { Deviation }\end{array}$ \\
\hline 1 & 67 & $7860.03^{\mathrm{a}}$ & 1241.02 \\
2 & 124 & $9010.01^{\mathrm{b}}$ & 1235.18 \\
3 & 51 & $10207.15^{\mathrm{c}}$ & 898.58 \\
4 & 62 & $10165.89^{\mathrm{c}}$ & 1100.29 \\
5 & 41 & $8430.57^{\mathrm{b}}$ & 1191.72 \\
6 & 47 & $8069.78^{\mathrm{a}}$ & 898.30 \\
Total & 392 & 8978.69 & 1427.64 \\
\hline
\end{tabular}

$\mathrm{a}, \mathrm{b}, \mathrm{c}$ : The difference between the groups is statistically significant shown with different letters in the same row $(\mathrm{p}<0.05)$.

\section{RESULTS}

In the present study, the mean lactation length between groups was similar with $334.5 \pm 10.21$ days $(p>0.05)$. It was determined that the lactation number of cows affects the annual total milk production. Milk production gradually increased significantly in the first 3 lactations, peaked at the 
3rd and 4th lactations, and then began to decline $(p<0.05)$. The effect of lactation number on milk yield is given in Table 1 . When considered economically, it was determined that the highest daily income was in the 3rd and 4th lactation periods (Table 2).

Table 2. Daily average milk production and milk income

\begin{tabular}{ccccc}
\hline $\begin{array}{c}\text { Lactation } \\
\text { Number }\end{array}$ & $\begin{array}{c}\text { Cow } \\
\text { Number }\end{array}$ & $\begin{array}{c}\text { Daily milk } \\
\text { yield Mean } \\
(\mathbf{k g})\end{array}$ & $\begin{array}{c}\text { Std. } \\
\text { Deviation }\end{array}$ & $\begin{array}{c}\text { Daily income } \\
\text { per cow } \\
\text { (1 L Milk=2.30 TL) }\end{array}$ \\
\hline 1.00 & 67 & $25.77^{\mathrm{a}}$ & 4.06 & 59.27 \\
2.00 & 124 & $29.54^{\mathrm{b}}$ & 4.04 & 67.94 \\
3.00 & 51 & $33.46^{\mathrm{c}}$ & 2.94 & 76.96 \\
4.00 & 62 & $33.33^{\mathrm{c}}$ & 3.60 & 76.66 \\
5.00 & 41 & $27.64^{\mathrm{ab}}$ & 3.90 & 63.57 \\
6.00 & 47 & $26.45^{\mathrm{a}}$ & 2.94 & 60.84 \\
Total & 392 & 29.43 & 4.68 & 67.69 \\
\hline
\end{tabular}

$a, b, c:$ The difference between the groups is statistically significant shown with different letters in the same row $(\mathrm{p}<0.05)$.

\section{DISCUSSION}

Milk and dairy products have an indispensable place in food and drink consumption. The globalizing modern dairy industry is constantly updated. And the economy and sustainability are always important in the farm industry (Borawski et al., 2020). For sustainable profitability in dairy farms, optimum milk production per dairy cow is required and can be considered as an indicator of financial success (Horvath and Miko, 2016).

The normal life expectancy of dairy cattle is about 20 years (De Vries and Marcondes, 2020). However, it is known that their care on dairy farms for such a long time is not economical for the farm industry. On the other hand, Groenendaal et al. (2004) reported that annual veterinary cost per cow increased by an average of $\$ 5$ each lactation. Therefore, dairy cows are used for milk production during their most economic and productive periods. The milk yield of dairy cows increases with age and decreases inversely proportional to aging after reaching the maximum level (Holodova et al., 2019). With a similar description, Grandl et al. (2016), reported that milk production increases during the first few lactations, reaches a flatness between 5 and 8 lactations, and then begins to decrease. In the present study, data of the first 6 lactation cows were used because there was a problem of finding cows in other lactation. The reason for this is that animals are culled from the herd due to disease and production problems.
Similarly, De Vries and Marcondes (2020) reported that the productive life of dairy cows in the most modern dairy industries is average 2.5 to 4 years. They were also declared that their total life span is between 4 and 6 years in most developed dairy industries because they are removed from the herd due to problems caused by high production. But we think that shortening in the average life expectancy of cows may also be related to management conditions. Because cows up to the 6th lactation are commonly used in production.

De Vries and Marcondes (2020) were declared healthy cows mature fully in approximately the 5th lactation and produce the most milk in this period. Similarly, Holodova et al. (2019) found that milk yield reached a peak in the 6th lactation. However, we determined that the lowest milk production was in 1st and 6th lactations and milk yield peaked in the 3rd and 4th lactations $(p<0.05)$. When the table is also examined, the milk yield and income of milk obtained per cow has increased by $30 \%$ on average during the $3 \mathrm{rd}$ and 4 th lactation periods compared to the 1st lactation period. These differences are thought to be due to milk yield, genetic differences, and management. However, the common point in our and other researchers' studies is that the milk yield starts to decrease again after reaching the peak level. This indicates that there is a decrease in the function of the udder tissue due to physiological aging. Snijders et al. (2000) were also noticed that dairy cows in 1st lactation had lower milk yield and body weight compared to dairy cows in 3rd lactation. Turiello et al. (2020) were reported that age at first calving associated with milk yield during the first lactation. However, the age and body weight were not taken into consideration in the present study. Dry period length can also affect lactation milk production in dairy cows ( $\mathrm{O}^{\prime}$ Hara et al., 2020). Kok et al. (2017) and Boujenane (2019) reported that dry period should be performed for optimum milk production at the next lactation. The ideal dry period length is considered to be 60 days (Boujenane, 2019). In the presented study, an average of 60 days' dry period was applied to all cows.

\section{CONCLUSION}

In conclusion, milk yields of healthy Holstein cows were compared during the first 6 lactations in this study. The findings obtained show that milk production increased in the first three lactations, 3 and 4 lactations remained stable and decreased in 5 th and 6th lactations. In terms of milk yield and 
income, the most economical periods were the 3rd and 4th lactation. Regardless of the number of lactations, it is considered economical to use healthy cows for milk production in dairy farms. However, this situation should be investigated for cows in the 7th lactation and older.

\section{ACKNOWLEDGMENTS}

Conflict of Interests: The authors declared that there is no conflict of interests.

Financial Disclosure: The authors declared that this study has received no financial support.

Author's Contributions: All authors (FE and SK) contributed to the study conception and design. Supervision/Consultancy (SK and FE), Data collecting (FE), Literature research (SK and FE), Writing the article (FE and SK), Critical review (FE and SK). All authors read and approved the final manuscript.

\section{REFERENCES}

Abuelo A, Hernández J, Benedito JL, Castillo C. Redox biology in transition periods of dairy cattle: Role in the health of periparturient and neonatal animals. Antioxidants. 2019; $8: 20$.

Bisinotto RS, Greco LF, Ribeiro ES, et al. Influences of nutrition and metabolism on fertility of dairy cows. Anim Reprod. 2012; 9:260-272.

Bórawski P, Pawlewicz A, Parzonko A, Harper J, Holden L. Factors shaping cow's milk production in the EU. Sustainability. 2020; 12:420.

Boujenane I. Factors affecting the dry period length and its effect on milk production and composition in subsequent lactation of Holstein cows. Iran J Appl Anim Sci. 2019; 9:229-234.

De Vries A, Marcondes MI. Overview of factors affecting productive lifespan of dairy cows. Animal 2020; 14:155-164.

Esposito G, Irons PC, Webb EC, Chapwany A. Interactions between negative energy balance, metabolic diseases, uterine health and immune response in transition dairy cows. Anim Reprod Sci. 2014; 144:60-71.

Grandl F, Amelchanka SL, Furger M, et al. Biological implications of longevity in dairy cows: 2. Changes in methane emissions and efficiency with age. J Dairy Sci. 2016; 99:3472-3485.

Groenendaal H, Galligan DT, Mulder HA. An economic spreadsheet model to determine optimal breeding and replacement decisions for dairy cattle. J Dairy Sci. 2004; 87:2146-2157.
Holodova LV, Novoselova KS, Mikhalev EV, Onegov AV, Chirgin ED. The effect of age on milk productivity and reproductive qualities of dairy cows. In IOP Conference Series: Earth Environ Sci. 2019; 315:022087.

Horvath J, Miko E. Impact of economic environment on herd size and milk production in a dairy cattle farm. Lucrări Științifice Management Agricol. 2016; 18:117-122.

Kok A, van Knegsel ATM, Van Middelaar CE, et al. Effect of dry period length on milk yield over multiple lactations. J Dairy Sci. 2017; 100:739-749.

LeBlanc S. Monitoring metabolic health of dairy cattle in the transition period. J Reprod Develop. 2010; 56:29-35.

O'Hara EA, Holtenius $K$, Båge $R$, Von Brömssen $C$, Emanuelson U. An observational study of the dry period length and its relation to milk yield, health, and fertility in two dairy cow breeds. Prev Vet Med. 2020; 175:104876.

Oltenacu PA, Broom DM. The impact of genetic selection for increased milk yield on the welfare of dairy cows. Anim Welfare. 2010; 19:39-49.

Short TH, Lawlor TJ. Genetic parameters of conformation traits, milk yield, and herd life in Holsteins. J Dairy Sci. 1992; 75:1987-1998.

Stott, AW. The economic advantage of longevity in the dairy cow. JAE. 1994; 45(1):113-122.

Snijders SEM, Dillon P, O'Callaghan D, Boland MP. Effect of genetic merit, milk yield, body condition and lactation number on in vitro oocyte development in dairy cows. Theriogenology. 2000; 53:981-989.

Tsioulpas A, Grandison AS, Lewis MJ. Changes in physical properties of bovine milk from the colostrum period to early lactation. J Dairy Sci. 2007; 90: 5012-5017.

Turiello MP, Vissio C, Heinrichs AJ, Issaly LC, Larriestra A. Impact of age at first calving on performance and economics in commercial dairy herds in Argentina. Livest Sci. 2020; 104108:1-6.

USK 2019. Ulusal Süt Konseyi, 2019 Yilı Çiğ Süt Tavsiye Fiyatları, https://ulusalsutkonseyi.org.tr/2019-yili-cig-sutfiyatlari-2019-2583/, (Accessed 20 July 2020).

Vijayakumar M, Park JH, Ki KS, et al. The effect of lactation number, stage, length, and milking frequency on milk yield in Korean Holstein dairy cows using automatic milking system. Asian Austral J Anim. 2017; 30:1093.

Walsh SW, Williams EJ, Evans ACO. A review of the causes of poor fertility in high milk producing dairy cows. Anim Reprod Sci. 2011; 123:127-138.

Zadoks RN, Fitzpatrick JL. Changing trends in mastitis. Ir Vet J. $2009 ; 62: 1-12$. 